\title{
De jure versus de facto Exchange Rate Stabilization in Central and Eastern Europe
}

\author{
Gunther Schnabl* \\ University of Tübingen
}

Die offiziellen IWF-Klassifikationen der mittel- und osteuropäischen Wechselkursregime sind heterogen. Während eine Gruppe von Ländern enge Wechselkursbindungen an den Euro berichtet, scheint eine zweite Gruppe zu flexibl(er)en Wechselkursregimen übergegangen zu sein. Basierend auf der Diskussion über die Richtigkeit der IWF-Wechselkursklassifikationen wird die Wechselkursstabilität in Mittel- und Osteuropa für hohe und niedrige Wechselkursfrequenzen untersucht. De facto ist die Wechselkursbindung an den Euro stärker als de jure. Die meisten mittel- und osteuropäischen Staaten stabilisieren ihre Wechselkurse gegenüber dem Euro und tragen somit zu einer wachsenden Eurozone bei. Trotzdem bleiben die intra-regionalen Wechselkursschwankungen weiter hoch, da bei den Wechselkursbindungen unterschiedliche Intensitäten und Strategien verfolgt werden.

Keywords: $\quad$ Foreign Exchange Policy, Fear of Floating, EMU, Euro Zone, Central and Eastern Europe

JEL-Codes: $\quad \mathrm{F} 31, \mathrm{~F} 33$

\section{More Exchange Rate Flexibility in Central and Eastern Europe?}

European integration has gained new momentum. In May 2004, ten mostly Central and Eastern European (CEE) countries (Czech Republic, Estonia, Hungary, Latvia, Lithuania, Poland, Slovak Republic, Slovenia, Cyprus, and Malta) have joined the European Union. Bulgaria and Romania are expected to follow by 2007 .

The Eastern enlargement of the EU raises the issue of adequate exchange rate strategies during the run-up to the European Monetary Union (EMU) (Buiter and Grafe 2002; Corker eT Al. 2000). As EU membership implies sooner or later accession to the European Exchange Rate Mechanism 2 (ERM2) and the EMU, exchange rate stabilization against the euro - as observed in Bulgaria, Estonia, Lithuania and Hungary - is a rational choice.

I thank Ronald MCKinNon, SLAVI SLAVov, participants of the ICEG conference "Exchange Rate Strategies During the EU Enlargement", and an anonymous referee for helpful comments. 
Nevertheless, a second group of countries has (officially) moved towards more exchange rate flexibility. Learning from the capital market-related crisis of the second half of the 1990s, and following official IMF advice (Mussa ET AL. 2000, p. 34; Fischer 2001), the Czech koruna (1997), the Slovak koruna (1998) and the Polish zloty (2000) have joined the Slovenian tolar in the group of de jure floating currencies (see Table 1). (More) flexible exchange rates, which may exhibit wide fluctuations within the $\pm 15 \%$ ERM2 band, will allow the new member states to better cope with speculative capital inflows during the EMU run-up (CORKER ET AL. 2000).

Table 1 De jure Exchange Rate Arrangements in Central and Eastern Europe

\begin{tabular}{|l|cccccc:cccccc:ccccc|}
\hline & 90 & 91 & 92 & 93 & 94 & 95 & 96 & 97 & 98 & 99 & 00 & 01 & 02 & 03 \\
Bulgaria & 3 & 8 & 8 & 8 & 8 & 8 & 8 & 2 & 2 & 2 & 2 & 2 & 2 & 2 \\
Czech Rep. & 3 & 3 & 3 & 3 & 3 & 3 & 6 & 7 & 7 & 7 & 7 & 8 & 8 & 8 \\
Estonia & n.a. & n.a. & 2 & 2 & 2 & 2 & 2 & 2 & 2 & 2 & 2 & 2 & 2 & 2 \\
Hungary & 3 & 3 & 3 & 3 & 3 & 6 & 6 & 6 & 6 & 6 & 6 & 4 & 4 & 4 \\
Latvia & n.a. & n.a. & 8 & 8 & 3 & 3 & 3 & 3 & 3 & 3 & 3 & 3 & 3 & 3 \\
Lithuania & n.a. & n.a. & 8 & 8 & 2 & 2 & 2 & 2 & 2 & 2 & 2 & 2 & 2 & 2 \\
Poland & 3 & 5 & 5 & 5 & 5 & 6 & 6 & 6 & 6 & 6 & 8 & 8 & 8 & 8 \\
Romania & 3 & 7 & 7 & 7 & 7 & 7 & 7 & 7 & 7 & 7 & 7 & 6 & 6 & 6 \\
Slovak Rep. & 3 & 3 & 3 & 3 & 3 & 3 & 6 & 6 & 7 & 7 & 7 & 7 & 7 & 7 \\
Slovenia & n.a. & n.a. & 7 & 7 & 7 & 7 & 7 & 7 & 7 & 7 & 7 & 7 & 7 & 7 \\
\hline
\end{tabular}

Notes: 1: exchange rate arrangements with no separate legal tender;

2: currency board arrangements;

3: other conventional fixed peg arrangements (within a band of most $\pm 1 \%$ );

4: pegged exchange rate arrangements within horizontal bands (at least $\pm 1 \%$;

5: crawling pegs (with small, pre-announced adjustment);

6: exchange rates with crawling bands;

7: managed floating with no pre-announced path for the exchange rate;

8: independent floating (market-determined exchange rate and independent monetary policy).

Source: IMF (various issues).

Given the arguments in favor of both more and less exchange rate flexibility against the euro, the heterogeneity of the CEE exchange rate classifications as shown in Table 1 is not surprising. Yet exchange rate stabilization against the euro might be de facto more prevalent than indicated. For 
instance, REINHART and ROGOFF (2002, p. 32) contend that "the official history of exchange rates can be profoundly misleading, as a striking number of pegs are much better described as floats, and vice-versa." Furthermore, CALVO and REINHART (2002) have measured the extent of open and hidden exchange rate stabilization for 155 exchange rate arrangements in 39 countries and identified a wide range of officially flexible exchange rates as pegged (fear of floating). LEVY-YEYATI and STURZENEGGER (2002) argue that an increasing number of countries have abandoned an explicit commitment to fixed exchange rate regimes, while the de facto exchange rate policies have remained quite stable (fear of pegging). MCKINNON and SCHNABL (2003) show for the post-crisis East Asian countries that exchange rates are much less flexible than suggested by IMF classifications.

\section{The Rationale for Exchange Rate Stabilization against the Euro}

What about Central and Eastern Europe? Frömmel and SchoberT (2003) argue that some CEE countries, such as Slovenia, have officially adopted inflation targeting frameworks while implicitly adhering to exchange rate targeting. The rationale for pegging to the euro is threefold. It springs from macroeconomic stability, lower transaction costs for intraEuropean trade, and lower risk premiums for short and long-term capital flows.

First, most emerging markets and developing countries lack a history of macroeconomic stability. Based on underdeveloped tax systems and government-controlled central banks, inflation tax is a common means of financing government expenditure. Since high inflation and depreciation discourage private consumption, (foreign direct) investment and international trade, establishing credibility through macroeconomic stability is a key objective for any economic consolidation process. Exchange rate pegs, which help anchor both inflation and expectations, have been an important tool for macroeconomic stabilization in Central and Eastern Europe. $^{1}$

For the CEE economies, which tried to stabilize inflation and public debt during the 1990s with mixed success, macroeconomic convergence has been

1 Since 1997 some countries have implemented inflation targeting frameworks instead (see FrömMEL and SCHOBERT 2003). 
a key element of the EU accession process. The EC Treaty states that the economic policies are of common concern and are to be coordinated (art. 103). Central bank loans to the government are prohibited (art. 104), and the member states must avoid excessive budget deficits (art. 104c). In line with this required macroeconomic convergence process, starting with the accession negotiations in 1998, inflation rates dropped and the gradual depreciation of many CEE currencies abated. The restrictions on macroeconomic policies, and thus the need for exchange rate stability against the euro ${ }^{2}$, are even tighter after EU accession. Although the new members are not expected to transfer their monetary sovereignty to the EU, inflation rates have to converge further towards the EMU benchmark as the new member states are integrated into the European System of Central Banks (ECB 2000, p. 46). The need for more exchange rate stability will be enhanced by ERM2 membership.

The second motivation for pegging to the euro stems from international goods markets. Although there has been no clear-cut evidence of a strong correlation between exchange rate stability and international trade (IMF 1984; EUROPEAN COMMISSION 1990), eliminating exchange rate uncertainty has been regarded as crucial for intra-EU trade integration. In support of this view, DE GraUwE's (1987) gravity model for intra-EMS trade between 1973 and 1985 finds a positive long-run correlation between less exchange rate volatility and more trade flows. More recently, ANDERTON and SKUDELNY (2001) have traced a statistically significant negative correlation between exchange rate volatility and trade among a panel of industrial countries.

Extending the argument to the case of a currency union, a gravity model by ROSE (2000) finds that irrevocably fixed exchange rates triple foreign trade. The result is reconfirmed by FRANKEL and ROSE (2002) who associate membership in the monetary union with considerable welfare gains. As Rose's (2000) sample is mainly based on small, low income countries, the effect might be less pronounced for larger or more developed countries (see Persson 2001). For instance, HM Treasury (2003) argues that for the United Kingdom the additional trade with the Euro Area resulting from EMU membership would be in the range of $5 \%$ to $50 \%$. To this end the benefits of (irrevocable) exchange rate stability against the euro for Central and Eastern European trade are twofold. As shown in Figure

2 De Grauwe and Schnabl (2003) explore the discrepancy between the Maastricht inflation and exchange rate criteria under the assumption of relative productivity increases (Balassa-Samuelson effect).

Reproduced with permission of the copyright owner. Further reproduction prohibited without permission. 
1, in the year 2002 CEE exports to the EU15 were $58.6 \%$ of total exports on average. Fixed exchange rates to the euro reduce the transaction costs for a substantial part of CEE trade. Further, based on DE GRAUWE (1987) and FRANKEL and ROSE (2002), the CEE countries can expect significant additional trade and welfare gains by further stabilizing exchange rates against the euro, and by joining the EMU. ${ }^{3}$

Figure 1 Exports to EU15 as Percentage of Overall Exports

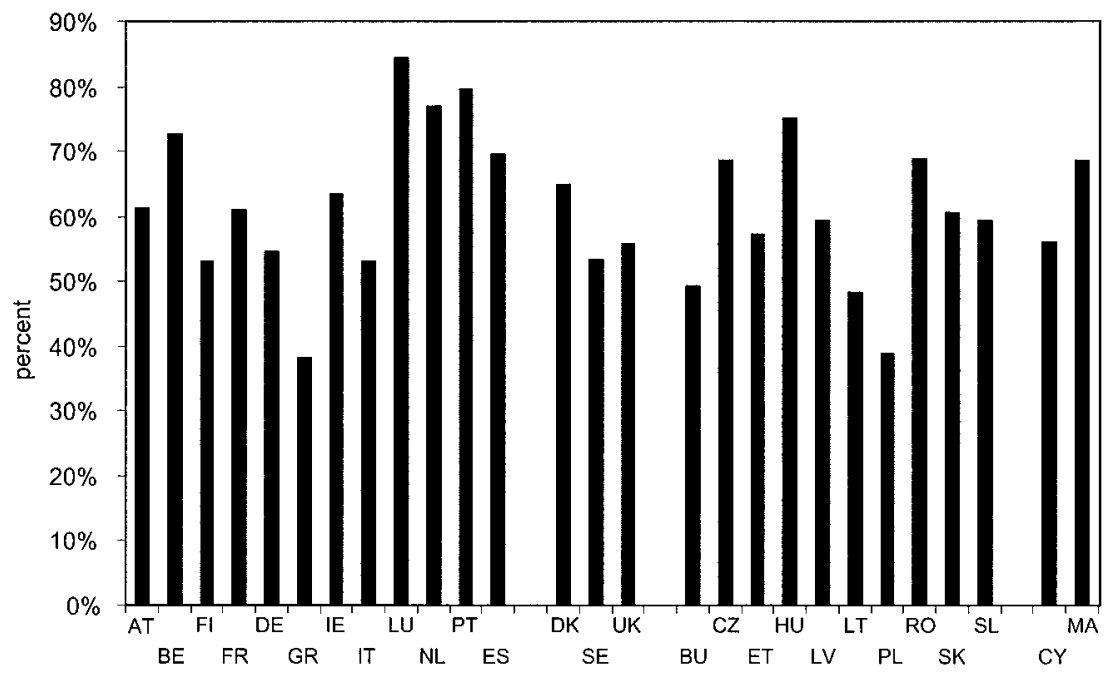

Source: IMF, Direction of Trade Statistics.

Third, the rationale for exchange rate stabilization in emerging markets springs from underdeveloped capital markets ("original sin") as put forward by EICHENGREEN and HAusmann (1999). Due to a long tradition of inflation and depreciation, banks and enterprises in emerging markets and developing countries cannot use the domestic currencies to borrow abroad or to borrow long-term, even domestically. The consequence is either a currency mismatch, i.e. projects that generate domestic currency are financed with foreign currency, or a maturity mismatch, i.e. long-term projects are financed with short-term loans. HAuSMAnN, PANIZZA and STEIN (2001) argue that due to this dollar (euro) liabilization, reducing long-term exchange rate fluctuations is equivalent to reducing default

3 DE GRAUwe and SCHNABl (2004) show the positive impact of exchange rate stability on growth in Central and Eastern Europe. 
risk on balance sheets. Indeed, econometric estimations by DEVEREUX and LANE (2002) find a strong negative relationship between the stock of external debt and low frequency exchange rate volatility relative to the creditor countries. ${ }^{4}$ MCKINNON and SCHNABL (2003) explain the motivation for exchange rate stability at high frequencies - i.e. daily or weekly exchange rate changes. With incomplete capital markets and thus missing forward markets, the aggregated foreign exchange risk of short-term external liabilities remains by definition unhedged. ${ }^{5}$ By stabilizing exchange rates on a day-to-day basis the government can provide an informal insurance for the foreign exchange rate risk of short-term capital flows.

Both arguments in favor of low and high frequency exchange rate stability apply for Central and Eastern Europe as capital markets remain underdeveloped despite some recent success in creating long-term government bond markets (see LANOO and SALEM 2001). With foreign bonds increasingly denominated in euro (ECB 2002, p. 28), the incentive to minimize long-term exchange rate swings against the euro is growing. The same applies for short-term capital flows because trade invoicing and thereby short-term payment transactions are dominated by euro (ECB 2003, pp. 33-34). Risk premiums on interest rates would shrink, thereby adding additional stimulus to the real convergence process (DORNBUSCH 2001).

From a future perspective, capital markets provide an additional incentive to adopt the euro as soon as possible. By joining the Euro Area - and having the unique chance to irrevocably import the reputation of the European Central Bank - the CEE economies would be spared the costs of building up their own capital markets.

\section{Formal Tests for Exchange Rate Flexibility}

Based on the strong rationale for euro exchange rate stabilization in Central and Eastern Europe, tests for exchange rate stabilization at high and low frequencies are carried out. For this purpose daily and monthly data are used. As outlined by MCKINNON and SCHNABL (2003), daily (high frequency) exchange rate data reflect the efforts of monetary authorities to minimize the exchange risk for short-term (capital market) transactions. Monthly data take a more long-term perspective and capture the efforts

4 Low frequency exchange rate volatility is defined as monthly, quarterly or yearly exchange rate changes.

5 In the highly developed capital markets of the industrial countries an investor can hedge an open position in foreign currency through financial derivates (forwards) at low cost. 
to reduce the exchange rate risk for trade flows and long(er)-term debt. At both lower and higher frequencies, exchange rate stabilization is interpreted in a broader sense than the hard pegs as pursued in Estonia or Lithuania. The attempts by monetary authorities to reduce exchange rate fluctuations on a daily or monthly basis, but allowing for more exchange rate flexibility in the medium term, are regarded as a (less restrictive) form of exchange rate stabilization. The respective degree of exchange rate stabilization is measured in comparison to the euro/dollar exchange rate as the most prominent fully flexible exchange rate.

\subsection{Low Frequency Exchange Rate Stability}

CAlvo and Reinhart (2002) use three criteria to test for de facto exchange rate stabilization: monthly (percentage) exchange rate changes, monthly percentage changes of official foreign reserves, and monthly absolute changes in nominal short-term interest rates. For all three criteria they set arbitrary probability limits to quantify the extent of exchange rate stabilization.

First, the degree of exchange rate fluctuations indicates stabilization efforts. In general, within an environment of free capital movement and the absence of government intervention, exchange rates will exhibit large und persistent fluctuations. If, for instance, the probability is high that monthly exchange rate changes fall outside a band of $\pm 2.5 \%$ (indicator $\varepsilon$ ), the currency is rated as freely floating. With a low probability the currency is classified as fixed. Second, governments stabilize exchange rates by intervening in foreign exchange markets. To prevent the domestic currency from appreciating (depreciating), the monetary authorities sell (buy) domestic currency in exchange for dollars, euros or yen. The stronger the efforts to stabilize the exchange rate, the higher the probability that monthly changes in official foreign reserves fall outside a predetermined band of $\pm 2.5 \%$ (indicator $\varphi_{1}$ ). ${ }^{6}$ Third, monetary policy can be a tool for exchange rate stabilization. To prevent the domestic currency from devaluation (ap-

6 Official foreign exchange reserves not only change with foreign exchange intervention but also for other reasons such as government payments in foreign currency and interest receipts on foreign exchange reserves (NEELY 2000, p. 22). Further, the dollar value of foreign exchange reserves will be altered if the dollar exchange rate of third currencies changes. Nevertheless, NEELY (2000) argues that there is a positive correlation between changes in official foreign reserves and foreign exchange intervention, with sharp increases in official foreign currency holding indicating intervention. Furthermore, some countries might require more foreign reserve transactions than others to achieve the same degree of exchange rate stability. Such an effect cannot be captured by the foreign reserves criterion. 
preciation) the government might increase (cut) interest rates. If the probability is high (low) that absolute interest rate changes fall outside a predetermined band of $\pm 4.0 \%$ CALVO and REINHART (2002) consider it to be an indication for (no) exchange rate stabilization via monetary policy (indicator $\mathrm{t}_{1}$ ).

To draw a more comprehensive picture of exchange rate stabilization in Central and Eastern Europe, the Calvo-Reinhart criteria are augmented in four regards. First, exchange variability against both the euro and the dollar is measured. Second, percent changes of foreign reserves, which are reported in US dollars, are measured in both dollars and euros. Third, as percentage changes of foreign reserves might be biased by the stock of foreign reserves, ${ }^{7}$ an alternative measure for exchange rate stabilization is added by dividing absolute changes of foreign reserves by the monetary base (indicator $\left.\varphi_{2}\right) .{ }^{8}$ The (arbitrary) band width is set to $\pm 5.0 \%$. Fourth, CALVO and ReINHART (2002) chose an arbitrary band of $\pm 4.0 \%$ for their interest rate criterion $\imath_{1}$. This bandwidth seems primarily appropriate to distinguish between high and low interest rate countries. ${ }^{9}$ As in most CEE countries the probability that short-term interest rates change by more than 400 basis points from one month to the other is small, the band is narrowed to $\pm 0.4 \%$ (indicator $\mathrm{t}_{2}$ ).

Table 2 gives an overview over the Calvo-Reinhart exchange rate criterion $(\varepsilon)$, the foreign reserve criteria $\left(\varphi_{1}\right.$ and $\left.\varphi_{2}\right)$, and the interest rate criteria $\left(\mathrm{l}_{1}\right.$ and $\left.\mathrm{t}_{2}\right)$ and their respective bands. ${ }^{10}$ According to CALVO and ReINHART (2002) their probability criteria are superior to the use of standard deviations as a measure of exchange rate volatility because they avoid distortions by outliers, particularly in the case of interest rates. Here, following HERNÁNDEZ and MONTIEL (2003) standard deviations are applied as additional indicators.

7 Given the same absolute change in foreign reserves, countries with a large stock of foreign reserves exhibit low percentage changes while countries with a small stock of foreign reserves exhibit high percentage changes.

8 As suggested by LEVY-YeYATI and STURZENEGGER (2002). For this purpose foreign reserves have to be reconverted from dollars into domestic currency which comprises a bias caused by changes in the dollar exchange rates of the CEE currencies.

9 For low interest rate countries the probability that the interest rate changes from one month to the other by more than \pm 4.0 percentage points is (close to) zero, independent from the exchange rate arrangement.

10 Sensitivity tests with different bands led by and large to the same results. 
Table 2 Indicators for Exchange Rate Stability

\begin{tabular}{|c|c|c|c|c|c|}
\hline \multirow[b]{2}{*}{ Criterion } & \multirow{2}{*}{$\begin{array}{c}\text { Exchange Rate (E) } \\
\varepsilon=\frac{e_{t+1}-e_{t}}{e_{t}}\end{array}$} & \multicolumn{2}{|c|}{ Foreign Reserves $(\varphi)$} & \multicolumn{2}{|c|}{ Interest Rate $(l)$} \\
\hline & & $\varphi_{t}=\frac{F_{t+1}-F_{t}}{F_{t}}$ & $\varphi_{2}=\frac{\left(F_{t+1}-F_{t}\right) * e_{t+1}}{M_{t+1}}$ & $l_{1}=i_{t+1}-i_{t}$ & $t_{2}=i_{t+1}-i_{t}$ \\
\hline & $\pm 2.5 \%$ & $\pm 2.5 \%$ & $\pm 5.0 \%$ & $\pm 4.0 \%$ & $\pm 0.4 \%$ \\
\hline
\end{tabular}

Source: author.

The observation period starts with the introduction of the euro in January 1999 and reaches up to the present with one exception. For Poland the observation period begins in April 2000 when it adopted flexible exchange rates. The euro/dollar exchange rate as well as the foreign reserves and the short-term interest rates of the free floaters Euro Area and the US are used as benchmarks.

Table 3 reports the results. According to the exchange criterion $\varepsilon$ all four countries officially classified as fixed exchange rate regimes show, in fact, very low exchange rate volatility against the euro or the dollar. Of course, the currency boards of Bulgaria and Estonia have eliminated exchange rate volatility against the euro almost completely. The same applies for the currency board of Lithuania against the dollar up to January 2002 and against the euro since February 2002. The Latvian lat, which has been stabilized against an SDR ${ }^{11}$ currency basket since 1994, exhibits low exchange rate variability against both euro $(18.33 \%)$ and dollar $(1.67 \%)$. The lower probability for the dollar is due to the higher weight of the dollar in the SDR based currency basket.

Hungary $^{12}$ (pegged exchange rate with horizontal band) and Romania (crawling peg) are presently classified as intermediate exchange rate arrangements by the IMF. Hungary shows rather small exchange rate variability against the euro. The probability of exceeding the \pm 2.25 band against the euro is $8.33 \%$ in comparison to $37.29 \%$ for the euro/dollar exchange rate. The Romanian leu (33.33\% against the euro and $31.67 \%$ against the dollar) resembles more the freely floating US dollar than a pegged currency.

11 Special Drawing Rights. Currently, as of January 2001, the SDR's composition is $45 \%$ US dollar, $29 \%$ euro, $15 \%$ Japanese yen, $11 \%$ British pound.

12 Hungary started shadowing the ERM2 exchange rate mechanism in 2001 with a fixed parity against the euro and horizontal bands of $\pm 15 \%$. In June 2003 the parity of the forint was devalued by $2.26 \%$ to facilitate the way into ERM2 by higher competitiveness of Hungarian exports in the EU markets. 


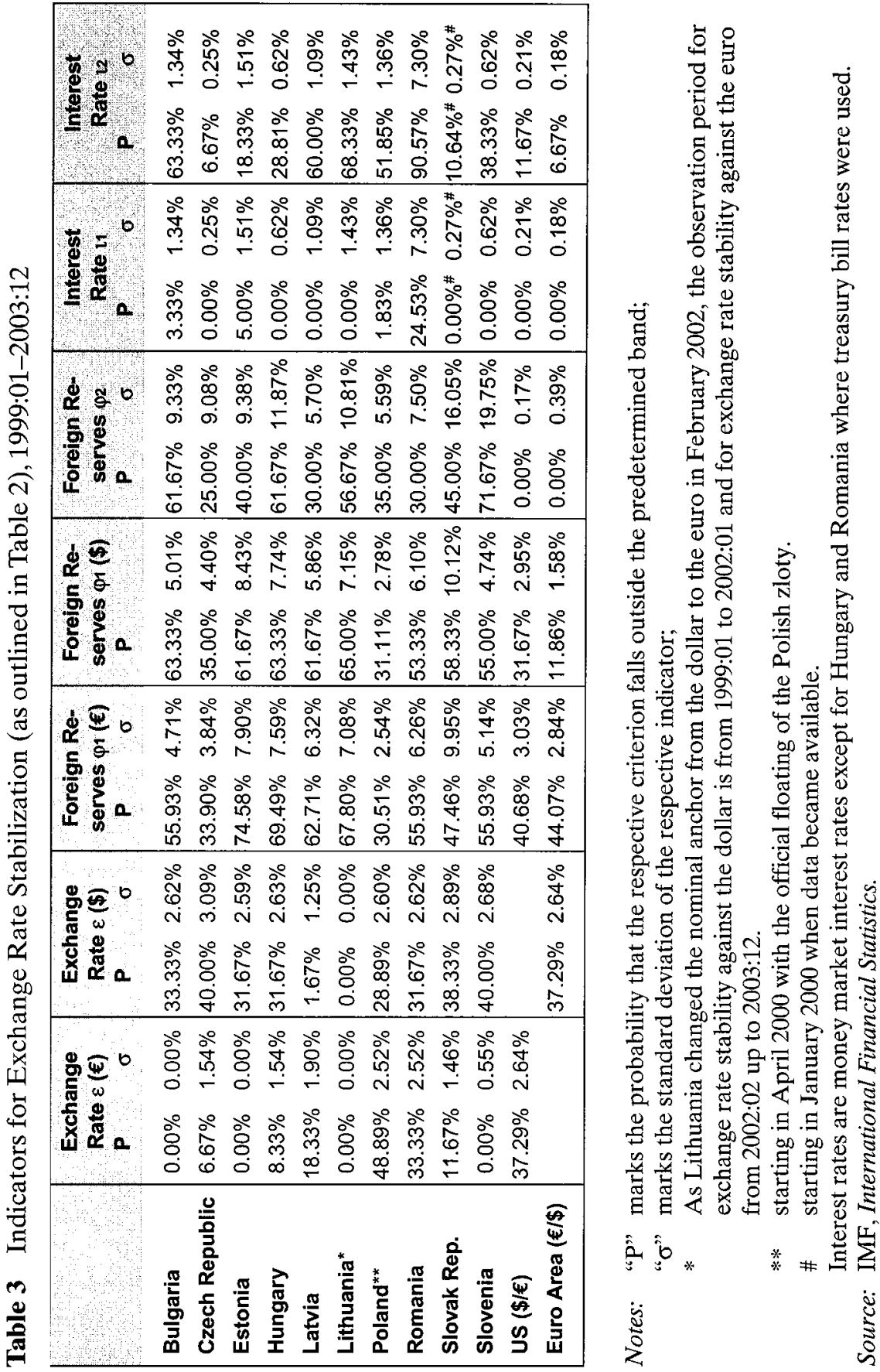

Reproduced with permission of the copyright owner. Further reproduction prohibited without permission. 
Out of the group of de jure free or managed floaters - the Czech Republic, Poland, the Slovak Republic and Slovenia - three countries seem to peg their currencies de facto to the euro. The Czech koruna (6.67\%), the Slovenian tolar $(0.00 \%)$ as well as the Slovak koruna $(11.67 \%)$ show a much lower probability that monthly exchange rate fluctuations exceed the $\pm 2.5 \%$ limit than the benchmark euro/dollar rate. Although the Slovenian tolar was allowed to depreciate gradually against the euro, exchange rate volatility has been considerably reduced. This corresponds to the notion that Slovenia had been shadowing the DM prior to 1999 and is now shadowing the euro. Only Poland (48.89\% against the euro and $28.89 \%$ against the dollar) and Romania (33.33\% against the euro and $31.67 \%$ against the dollar) exhibit an exchange rate volatility similar to the euro/dollar exchange rate (37.29\%) and can be classified as free floaters according to the exchange rate criterion $\varepsilon$. The standard deviations of monthly exchange rate changes support these results.

In contrast to the exchange rate criterion $\varepsilon$, the foreign reserves criterion $\varphi_{1}$ has to be interpreted more diligently, as outlined above. When testing for the variability of foreign reserves measured in euro, for most CEE countries the probability that monthly changes of official foreign reserves exceed $\pm 2.5 \%$ is higher than for the US $(40.68 \%)$ and the Euro Area (44.07\%). But for Poland (30.51\%) and the Czech Republic (33.90\%) the probability is lower than for the benchmark free floaters. Romania $(55.93 \%)$ is not identified as a freely floating currency, as suggested by the exchange rate criterion $\varepsilon$. Measuring foreign reserves in US dollars yields only slightly different results.

While the CALvo and ReINHART (2002) foreign reserves criterion $\varphi_{1}$ does not produce a result completely consistent with the exchange rate criterion $\varepsilon$, the indicator $\varphi_{2}$ might provide additional information about the scope of foreign exchange intervention relative to the size of the monetary base. Table 3 shows the distinct difference between the large freely floating economies US and Euro Area and the small open economies of Central and Eastern Europe based on the foreign reserves criterion $\varphi_{2}$. For the US and the Euro Area the probability that monthly changes of foreign reserves are larger than $5.0 \%$ of the monetary base is zero. In contrast, for the CEE countries the probabilities range from $25.00 \%$ in the Czech Republic up to $71.67 \%$ in Slovenia, showing the significant size of exchange rate stabilization relative to the monetary base. 
Among the CEE economies the changes of foreign reserves relative to the monetary base are comparatively low for the Czech Republic $(25.00 \%)$, for Poland (35.00\%) and for Romania (30.00\%), which possibly indicates less active foreign exchange intervention. But for Latvia the value is also comparatively low (30.00\%). The remaining countries range from $40.00 \%$ (Estonia) to $71.67 \%$ (Slovenia).

Finally, the interest rate criteria $\imath_{1}$ and $\imath_{2}$ are intended to reveal exchange rate stabilization via short-term interest rates. Absolute changes of nominal interest rates classified by a bandwidth of \pm 400 basis points $\left(l_{1}\right)$ draw a borderline between the high inflation country Romania and the remaining countries, including the US and Euro Area. Reducing the bandwidth to \pm 40 basis points allows the identification of countries with extraordinarily sharp interest rate changes, such as Bulgaria, Latvia, Lithuania and Poland. Again the Czech Republic seems to be an outlier as the probability that interest rate changes are less than $\pm 0.4 \%$ per month $(6.67 \%)$ is less than in the US (11.67\%) and equal to the Euro Area $(6.67 \%)$. The Slovak Republic (10.64\%) also has a value similar to the US. To this end the interest rate criterion does not seem to allow reliable statements about exchange rate stabilization.

All in all, based on the low-frequency criteria as listed in Table 3, Bulgaria, Estonia, Hungary, Lithuania, the Slovak Republic and Slovenia are identified as having pegged their exchange rates to the euro. Latvia has pursued an intermediate strategy by pegging to both euro and dollar. Poland has adhered to the free float since the year 2000. The Czech koruna and the Romanian leu can not be clearly identified as pegged or floating currencies. While the Czech koruna exhibits low exchange rate variability against the euro, this exchange rate stabilization is not reflected in the variability of foreign reserves and interest rates. Nevertheless, due to the quickly rising level of Czech foreign reserves $^{13}$, there is an indication of persistent exchange rate stabilization. In Romania, while the volatility of foreign reserves and interest rates is high, exchange rate volatility has been high as well.

13 Foreign reserves as a percentage of GDP climbed from $22 \%$ in 1998 to $31 \%$ in 2003 (US $0.36 \%$ in 2003). 


\subsection{High Frequency Exchange Rate Stability}

High frequency data might provide additional evidence on the CEE exchange rate strategies. As shown by MCKINNON and SCHNABL (2003), daily exchange rate returns reflect the daily attempts of central banks to smooth out exchange rate fluctuations. If the volatility of daily returns is significantly smaller than for the euro/dollar rate this indicates pegging at high frequencies. To measure daily exchange rate volatility we use the zscore $\left(z=\sqrt{\mu^{2}+\sigma^{2}}\right)$ as proposed by GHOSH, GULDE and WOLF (2003), which incorporates both exchange rate fluctuations around a gradual depreciation path and exchange rate fluctuations around a constant level. The parameter $\mu$ corresponds to the arithmetic average of daily percentage changes in the exchange rate while $\sigma$ corresponds to the standard deviation of the daily percentage changes in the exchange rate.

Table 4 reports the $\mathrm{z}$-scores of the daily exchange rate returns against euro and dollar for the CEE sample. The observation period is from January 1, 1999 up to March 31,2004. The z-scores of daily percentage exchange rate changes are, of course, lowest for the currency board arrangements of Bulgaria (0.05\% against the euro), Estonia (0.09\% against the euro) and Lithuania $(0.02 \%$ against the euro since February 2002).

Table 4 Dailv Exchange Rate Volatilities against Euro and Dollar

\begin{tabular}{|l|c|c|}
\hline 01/01/99-03/31/04 & Euro & Dollar \\
Bulgarian lev & $0.05 \%$ & $0.62 \%$ \\
Czech koruna & $0.36 \%$ & $0.68 \%$ \\
Estonian kroon & $0.09 \%$ & $0.64 \%$ \\
Hungarian forint & $0.40 \%$ & $0.69 \%$ \\
Latvian lat & $0.44 \%$ & $0.26 \%$ \\
Lithuanian lita* & $0.66 \%](0.02 \%)$ & {$[0.02 \%](0.61 \%)$} \\
Polish zloty & $0.67 \%$ & $0.63 \%$ \\
Romanian leu & $0.82 \%$ & $0.58 \%$ \\
Slovak koruna & $0.31 \%$ & $0.72 \%$ \\
Slovenian tolar & $0.22 \%$ & $0.65 \%$ \\
\hline euro/dollar & $0.67 \%$ & $0.67 \%$ \\
\hline
\end{tabular}

Notes: Volatility defined as standard deviations $(\sigma)$ and arithmetic averages $(\mu)$ of daily exchange rate returns $\left(z=\sqrt{\mu^{2}+\sigma^{2}}\right)$.

* Note two sub-samples for Lithuania due to the shift in exchange rate regime: $[01 / 01 / 99-01 / 30 / 02]$ and $(02 / 01 / 02-03 / 31 / 04)$, respectively.

Source: Datastream. 
For the Czech koruna ( $0.36 \%$ against the euro), the Hungarian forint $(0.40 \%$ against the euro), the Latvian lat $(0.44 \%$ against the euro and $0.26 \%$ against the dollar), the Slovak koruna $(0.31 \%$ against the euro), and the Slovenian tolar $(0.22 \%$ against the euro) the z-scores are higher than for the currency board countries but significantly lower than for the benchmark euro/dollar rate $(0.67 \%)$, thus indicating exchange rate stabilization against the euro. The Polish zloty and the Romanian leu have high standard deviations against both euro and dollar and thereby can be classified as freely floating currencies. ${ }^{14}$

\section{The Path towards the Euro Zone}

The tests for low und high frequency exchange rate stabilization as performed in Section 3 yield similar results. Based on the strong rationale for exchange rate stabilization against the euro as outlined in Section 2, euro pegs are much more prevalent in Central and Eastern Europe than suggested by de jure exchange rate classifications. We observe a growing euro zone consisting of Bulgaria, the Czech Republic, Estonia, Hungary, Lithuania, the Slovak Republic and Slovenia. Latvia pegs its currency to a currency basket which is dominated by the dollar (45\%) and the euro $(29 \%)$. Only two countries - Poland and Romania - remain completely outside the euro zone.

Figure 2 summarizes the development of euro and dollar as anchor currencies in Central and Eastern Europe starting from the beginning of the CEE transformation process in the early 1990s. On the vertical axis a value of $100 \%$ corresponds to a complete dollar or euro zone, respectively. The quarterly values for euro and dollar are computed as follows: up to 1997 pegging to currency baskets prevailed in Central and Eastern Europe. The composition of the currency baskets is taken from the official IMF classifications ${ }^{15}$ if there is no indication for a discrepancy between de facto and de jure exchange rate arrangements. The specific weights of the dollar and the aggregated weight of all European currencies are listed in the respective quarters of observation starting in the first quarter of 1990. For instance, for Hungary in 1990:01, a value of $0.426(42.6 \%)$ is attribut-

\footnotetext{
14 The standard deviations of the Romanian leu of $0.83 \%$ against the euro and of $0.57 \%$ against the dollar might indicate (some) exchange rate stabilization against the dollar as argued by FRÖMMEL and SCHOBERT (2003).

15 See IMF (various issues).
} 
ed to the dollar and a value of $0.574(57.4 \%)$ is attributed to the European currencies ${ }^{16}$.

Figure 2 Euro and Dollar as Anchor Currencies in Central and Eastern Europe (1990-2003)

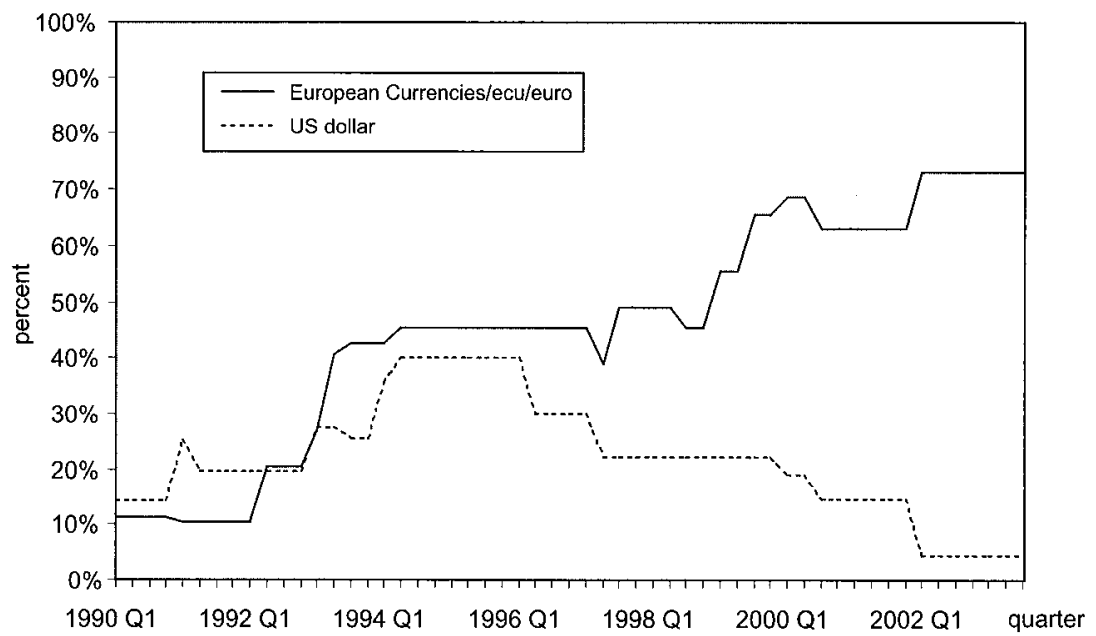

Source: IMF (various issues); own calculations (arithmetic averages).

If a country has adopted a unilateral peg, for instance to the euro, the maximal value of $1(100 \%)$ is attributed to the euro, and 0 is attributed to the dollar. If there is no information about exchange rate stabilization or the exchange rate is independently floating the value of 0 is listed for both euro and dollar. Further, if there is evidence that a currency is de facto pegged to the euro while de jure classified as a free float - as in the case of Slovenia and the Czech Republic after 1999 - 1 instead of 0 is attributed to the euro. When the exchange rate arrangements or the weights in the currency baskets change, the values are adjusted in the respective quarter. Finally, for every quarter the arithmetic mean is calculated. ${ }^{17}$

Figure 2 shows the time path of pegging to the dollar and to the European currencies (euro since January 1999). The dotted line marks pegging to the dollar. While during the mid-1990s the dollar had reached a consi-

16 German mark, Austrian shilling, Swiss franc, Italian lira, French franc, British pound, Swedish krona, Dutch guilder, Finish mark and Belgian franc.

17 A weighted average by country size (GDP) would lead to a lower level of euro pegging since 1997 as the large countries (Poland and Romania) have pursued flexible exchange rate arrangements. 
derable role as anchor currency in Central and Eastern Europe, the advent of the euro and the EU Eastern Enlargement have triggered a steady decline. After the shift of the Lithuanian currency board from dollar to euro in January 2002, the dollar presently only retains a weight of $45 \%$ percent in the Latvian currency basket. When Latvia joins ERM2 this residual will also vanish. The bold line represents the pegging to all European currencies and since January 1999 to the euro. Up to 1998 several CEE countries pegged their currencies to the German mark or currency baskets which contained a considerable number of Western European currencies (in some cases ECU). Representing the sum of the respective cumulated weights, Figure 2 shows that the weight of the European currencies grew steadily up to 1994 and then remained by and large constant between $40 \%$ and $50 \%$. After the advent of the euro in January $1999-$ despite the worldwide wave of exchange rate crisis in 1997/98 and despite the shift of Poland to flexible rates - euro pegging has reached a record high in the new millennium.

After the first wave of EU accession the euro zone can be expected to grow further, approaching the $100 \%$ mark. As all new EU members will be expected to join ERM2 some time after accession, fully floating exchange rates as in Poland and pegs against anchors other than the euro as in Latvia will be incompatible with ERM2 (see ECOFIN 2000). Romania will remain the only outsider of the CEE euro zone. Furthermore, the rise of the euro zone will not be restricted to the new Central and Eastern European accession countries and the (still) EMU opt-outs Denmark, Sweden and UK. Given the network externalities of a large euro zone as stressed by PORTES and REY (1998) the countries at the periphery of the growing European Monetary Union might find it attractive to stabilize exchange rates against the euro. Even today reduced daily exchange rate fluctuations against the euro indicate that also Croatia, Morocco, Norway, Switzerland and Tunisia peg their currencies more or less tightly to the euro. Other countries such as Bosnia-Herzegovina, Montenegro and Macedonia have adopted tight currency board arrangements or use the euro as legal tender. In Yugoslavia the euro circulates as an unofficial currency.

To this end, the euro zone already exceeds the scope of the present and potential EMU members. With the euro zone undergoing such growth, other countries at the periphery such as Russia, Belarus, Ukraine, Algeria, Egypt or Turkey might reconsider their exchange rate strategies. The euro may challenge the dollar as an international currency. 


\section{Outlook}

Based on a variety of tests for de facto low and high frequency exchange rate stabilization, this paper has shown that Central and Eastern European exchange rate stabilization against the euro is much more prevalent than suggested by IMF classifications. Based on a strong rationale for euro stabilization, the euro zone in and around Europe is growing steadily.

There is one caveat, however. The tests performed in Section 3 were based on a relatively wide concept of exchange rate stabilization. It comprises rigid currency boards (Bulgaria, Estonia and Lithuania), a pegged rate with wide horizontal bands (Hungary), a downward crawling peg (Slovenia), a currency basket with $29 \%$ euro weight (Latvia), and more discretionary exchange rate stabilization with appreciation drift as observed in the Czech and Slovak Republics. The exchange rate strategies in Central and Eastern Europe are still far from being unified.

Also ERM2 membership is unlikely to make the CEE exchange rate strategies completely homogenous, as the relative wide ERM2 band will allow for a broad variety of stabilization strategies (DE GRAUWE and SCHNABL 2003). In particular, Poland, by far the largest CEE economy, might continue to pursue a comparatively flexible exchange rate strategy. This implies a considerable degree of intra-regional exchange rate fluctuations which can be associated with higher costs for intra-regional trade and a higher degree of macroeconomic instability.

This leaves us with the question of a more homogenous exchange rate strategy in Central and Eastern Europe. The common peg to dollar fostered intra-regional trade and macroeconomic stability in East Asia, as observed by MCKINNON and SCHNABL (2003). The intra-regional CEE trade integration is still rather weak. A further unification of the CEE exchange rate strategies could contribute to more intra-regional trade integration and macroeconomic stability, thus adding an additional growth stimulus for the whole region. 
Anderton, Robert and Frauke Skudelny (2001), Exchange Rate Volatility and Euro Area Imports, ECB Working Paper No. 64.

Buiter, Willem and Clemens Grafe (2002), Anchor, Float or Abandon Ship: Exchange Rate Regimes for Accession Countries, CEPR Discussion Paper No. 3184.

Calvo, Guillermo and Carmen Reinhart (2002), Fear of Floating, Quarterly Journal of Economics 117, pp. 379-408.

Corker, Robert, Craig Beaumont, Rachel van Elkan, and Dora IAKova (2000), Exchange Rate Regimes in Selected Advanced Transition Economies - Coping with Transition, Capital Inflows, and EU Accession, IMF Policy Discussion Paper No. PDP/00/03.

De Grauwe, Paul (1987), International Trade and Economic Growth in the European Monetary System, European Economic Review 31, pp. 389-398.

De Grauwe, Paul and Gunther Schnabl (2003), Nominal Versus Real Appreciation with Respect to EMU Accession. How to Cope with the Balassa-Samuelson Dilemma?, Internet: http://econwpa.wustl.edu: 8089/eps/if/papers/0403/0403008.pdf (downloaded April 30, 2004).

De Graume, Paul and Gunther Schnabl (2004), Exchange Rate Regime and Macroeconomic Performance in Central and Eastern Europe, CESIfo Working Paper No. 1182.

Devereux, Michael and Philip Lane (2002), Understanding Bilateral Exchange Rate Volatility, CEPR Discussion Paper No. 3518.

Dornbusch, RÜDIgER (2001), Fewer Monies Better Monies, Discussion on Exchange Rates and the Choice of Monetary-Policy Regimes, American Economic Review 91, pp. 238-242.

ECB [European Central Bank] (2000), The Eurosystem and the EU Enlargement Process, ECB Monthly Bulletin, February 2000, pp. 39-51.

ECB [European Central Bank] (2002), Review of the International Role of the Euro, Frankfurt.

ECB [European Central Bank] (2003), Review of the International Role of the Euro, Frankfurt.

ECOFIN [Council of Economics and Finance Ministers of the European Union] (2000), Exchange Rate Strategies for Accession Countries Council Conclusions, Brussels.

EICHENGREen, BARRY and Ricardo Hausmann (1999), Exchange Rates and Financial Fragility, NBER Working Paper No. 7418, Cambridge, Mass.: National Bureau of Economic Research. 
European Commission (1990), One Market, One Money: An Evaluation of the Potential Benefits and Costs of Forming an Economic and Monetary Union, European Economy 44.

Fischer, STANLEy (2001), Exchange Rate Regimes: Is the Bipolar View Correct?, Journal of Economic Perspectives 15, pp. 3-24.

Frankel, JEFFREY and ANDREW Rose (2002), An Estimate of the Effect of Common Currencies on Trade and Income, Quarterly Journal of Economics 117, pp. 437-466.

Frömmel, Michael and Franziska Schobert (2003), Nominal Anchors in EU Accession Countries - Recent Experiences, Hannover University Discussion Paper No. 267.

Ghosh, Atish, Anne-Marie Gulde and Holger Wolf (2003), Exchange Rate Regimes. Choices and Consequences, Cambridge, Mass.: MIT Press.

Hausmann, Ricardo, Ugo Panizza and Ernesto Stein (2001), Why Do Countries Float the Way they Float? Journal of Development Economics 66, pp. 387-414.

Hernández, Leonardo and Peter Montiel (2003), Post-Crisis Exchange Rate Policy in Five Asian Countries: Filling in the "Hollow Middle"?, Journal of the Japanese and International Economies 17, pp. 336-369.

HM Treasury (2003), EMU and Trade, London.

IMF [International Monetary Fund] (1984), Exchange Rate Variability and World Trade, IMF Occasional Paper No. 28.

IMF [International Monetary Fund] (various issues), Annual Report on Exchange Rate Arrangements and Exchange Restrictions, Washington D.C.

Lanoo, Karel and Tanja Salem (2001), The Emerging Regulatory Framework for Banking and Securities Markets in the CEECs, in: Michael Schröder (ed.), The New Capital Markets in Central and Eastern Europe, Berlin: Springer Verlag, pp. 85-123.

LeVy-Yeyati, Eduardo and Federico Sturzenegger (2002), Classifying Exchange Rate Regimes: Deeds vs. Words, mimeo, Internet: http:// www.utdt.edu/ fsturzen/DW2002.pdf (downloaded April 30, 2004).

McKinnon, Ronald and GunTher Schnabl (2003), The East Asian Dollar Standard, Fear of Floating, and Original Sin, Stanford University Discussion Paper No. 2003/02.

Mussa, Michael, Paul Masson, Alexander Swoboda, Esteban Jadresic, Paolo Mauro and Andrew Berg (2000), Exchange Rate Regimes in an Increasingly Integrated World Economy, IMF Occasional Paper No. 193. 
NeEly, Christopher (2000), Are Changes in Foreign Exchange Reserves Well Correlated with Official Intervention, Federal Reserve Bank of St. Louis Review 82 (5), pp. 16-31.

Persson, Torsten (2001), Currency Unions and Trade: How Large is the Treatment Effect?, Economic Policy 33, pp. 435-461.

Portes, Richard and Hélène Rey (1998), Euro vs Dollar. Will the Euro Replace the Dollar as World Currency? Economic Policy 26, pp. 306-343.

ReInHART, CARMEN and Kenneth Rogoff (2002), The Modern History of Exchange Rate Arrangements: A Reinterpretation, NBER Working Paper No. 8963, Cambridge, Mass.: National Bureau of Economic Research.

Rose, ANDREw (2000), Currency Unions: Their Dramatic Effect on International Trade, Economic Policy 28, pp. 9-45. 